\title{
Assessment of In-vitro culture through Nodal explants of Dendrocalamus hamiltonii
}

\author{
Abha Jha ${ }^{1, *}$ and Sunila Das ${ }^{2}$ \\ ${ }^{1}$ HPS College Nirmali, BNMU Madhepura, India \\ ${ }^{2}$ C. M. Sc. College Darbhanga, India \\ Corresponding authore-mail: abhajha202@gmail.com \\ (Received: 11/11/2020; Revised: 10/04/2021; Accepted: 15/06/2021)
}

\begin{abstract}
The present experimental study was aimed to overcome the traditional methods of propagation that limit the number of propagules by in-vitro regeneration through nodal explants of Dendrocalamus hamiltonii with a comparative study of growth regulators during the shooting and rooting process. Dendrocalamus hamiltonii is distributed from the Himalayas (Nepal) to the northern part of Burma. Collection of explants was done from different selected sites of CPTs. There was the use of $\mathrm{HgCl} 2$ and $\mathrm{Ca}(\mathrm{OCl}) 2$ as sterilizing agents in different concentrations and its effect was visualized during the sprouting stage. Culm explants were cultured in a bottle containing White media (Wm) supplemented with BA and Kinetin for sprouting and IAA, IBA, NAA for rooting. There is also the use of $\mathrm{IAA}+\mathrm{IBA}+\mathrm{NAA}$ in combined form as a supplementary solution $0.1 \% \mathrm{HgCl} 2$ treatment for 20 -minute results into $77.80 \%$ aseptic buds and $72 \%$ bud -break. Among the used growth-hormones, BA with concentration $0.25 \mathrm{mg} / 1$ and $0.50 \mathrm{mg} / \mathrm{l}$ respectively were appropriate for shoot-multiplication rate, $4.01 \pm 0.3$ and $4.3 \pm 0.4$ were ideal observation incorporation with BA (1.00mg/l) and BA (1.50mg/l) respectively. Maximum sprouting rate $14.77 \pm 3.37$ with application of $\mathrm{BA}(2.00 \mathrm{mg} / \mathrm{l})$ and maximum shoot length $4.3 \pm 0.4$ is observed at BA $(1.50 \mathrm{mg} / \mathrm{l})$. The applications of rooting hormone IAA+IBA+NAA in the concentration of $1.0 \mathrm{mg} / \mathrm{l}$ results in $72.5 \pm 0.3$ (rooting) and $11.1 \pm 0.3$ (av. No. of the root).
\end{abstract}

Keywords: $\mathrm{CPT}_{\mathrm{s}}, \mathrm{HgCl}_{2}$, sterilizing agents, $\mathrm{BA}$, Kinetin, sprouting rate

\section{INTRODUCTION}

Dendrocalamus hamiltonii Arn Ex Munro is a large tufted thin-walled bamboo with erect culms and large branches. It belongs to the grass family Poaceae; and subfamily Bambusoideae. The distinguishing features of this species are brown pubescent culm with bent top in mature culms, root verticils that are seen in almost all the nodes of the culm, largely broad ovate branch buds, and zig-zag internodes in some culms (Alam 1982). It grows very fastly and rapidly. The culms reached a height of $24-27 \mathrm{~m}$. with a diameter of $15-18 \mathrm{~cm}$. This species is distributed scarcely in Northeast Himalayas, Sikkim, Arunachal Pradesh, Assam, Manipur, Meghalaya, Mizoram, Nagaland, and Tripura. It is versatile and used as a very widely renewable resource. More than 3500 traditional and 1200 commercial applications have been identified and applied to our daily life. The species can be multiplied from seedlings by separating tillers (Adarsh Kumar et al., 1985). This species can also be propagated easily by rooting culm cuttings using growth regulators (Nath et al. 1986). For rooting, culm cutting from the basal nodes of the oneyear-old culm is ideal (Sharma and Kaushal, 1985). Like other bamboos, it is also propagated vegetatively through stem and rhizome cuttings. Conventional methods of propagation are based on seeds and vegetative methods. As the availability of seeds is limited for a certain specific period and the viable period is very short, to overcome this problem; propagation through offset, rhizome cutting, culm cutting, and layering is the alternate option. All these conventional methods do not fulfill the demand of the market. In this condition, micropropagation ensures a continuous supply of bamboo planting materials in a very short time. The supply and demand scenario in bamboo-producing countries indicates that demand is much greater than production (Ramanuja Rao 1994). It is only in Japan that demand for bamboo has declined (Masatoshi, 1994). Successful multiplication of shoots derived from nodal explants from the adult plants of B. bamboos, B. vulgaris, and D. strictus (Nadgir, Phadke, Gupta, 1984).

\section{MATERIALS AND METHODS}

The nodal explants $(2.0-2.5 \mathrm{~cm})$ had been collected from the selected healthy CPTs of Dendrocalamus hamiltonii of natural bamboo clumps from Pauhaddi village of Benipur under Darbhanga district of Bihar state. Survey and sampling of CPTs were done preciously during the transact walk of identified geography. The collection 
of explants was done very carefully and minutely from selected CPTs. Collected nodal segments were cut into single nodal explants. the laboratory work was carried out at C.M. Science College, LNMU Darbhanga; Bihar, India during the rainy season of 2012.It is situated between longitude 85 degree 45 minute- 86 degree 25 minute East and latitude 25 degrees 53 minute-26 degree 27 minute North and is bounded by Madhubani district on the south by Samastipur district, on the east by Saharsa district, and on the west by Sitamarhi and Muzaffarpur district. These explants were pre-treated with a $0.5 \%$ dilute solution of Bavistin, a fungicide for 15 minutes. Thereafter, pre-treated segments were washed with antiseptic (Savlon) solution and then under running tap water 2-3 times, consequently for 2-min. each. Now the basal sheaths covering the axillary buds were to be removed and shaped with the help of scalpels. Thereafter, segments were surface sterilized with $0.1 \% \mathrm{HgCl} 2$ solution for $5 \mathrm{~min}$. The experimental contaminants were easily removed by washing in running water for 30-90 minutes and disinfected with surface sterilizing agents such as fungicides, alcohols, $\mathrm{HgCl} 2$, and $\mathrm{NaOCl}$. The success of sterilization depends upon the concentration, duration, and antimicrobial agents (Oyebanji et. al., 2009). Mercuric chloride is often used to overcome microbial contamination, however, it is considered as one of the most toxic elements for the ecosystem, capable of causing a major alteration in the tissue of both animals and humans (Lund et. al., 1993). Others have used Sodium hypochlorite and chlorine water for surface sterilization (Rao et al.; 1985, Yeh and Chang, 1986 a, b). White's medium containing solidifying agents' agar with or without growth regulators IAA, IBA, NAA, Kinetin, and IAA+IBA+NAA in different concentrations, were prepared. Before this, sterilization of lab agents, culture-bottle, and other using apparatus was done very carefully. First, the collections of explants were done in September and were cultured in prepared media Whites media supplemented with $100 \mathrm{mg} / \mathrm{l}$, myoinositol, sucrose (3\%), and $0.75 \%$ agar were used for culturing the explants. Different concentrations of growth regulators like BA, IAA, NAA, IBA, and Kinetin were used in the medium. The $\mathrm{pH}$ of the medium was adjusted to 5.7. The media was sterilized in an autoclave at $1210 \bullet \mathrm{C}, 15 \mathrm{lb}$ pressure for $15 \mathrm{~min}$. Sterilized nodal segments were cultured in the semisolids White's agar medium in a culture bottle in an inoculation chamber under controlled conditions. Cultured buds sprouted within 3-5 weeks; sprouted buds were sub-cultured and transferred in other bottles containing the same media. After some time, sprouted portion developed and growth took place up to elongated shoots. Elongated shoots were used as explants either in a single form or in cluster form to produce multiple shoots and root inductions. When roots were well developed, plantlets were removed from culture media and tap water and thus transferred to hykopot containing cocopeat and vermicompost into 3:1ratio.

\section{Hardening, Acclimatization, and Field Transfer}

After 3 weeks, healthy rooted plantlets were transferred to seedling trays containing transplanting media (soil+ riverbed sand+ FYM/vermicompost) in a maintained mist chamber for 2-3 weeks. After that under optimum condition; prepared plantlets were to be transferred to the trial field for better survival and vigorous growth.

\section{RESULTS AND DISCUSSION}

Statistically analyzed mean data disclosed that all characters under observation have a significant role during the experiment. After 2-3 weeks; cultured plants were sprouted, but some explants failed to green for a long time, didn't sprout, and dried up. Seasonal effect on axillary bud breaking was observed by Saxena and Bhojwani in 1993 on D. longispathus. Different methods of sterilization were applied for different durations such as 10,15 , and 20 min.with both $\mathrm{HgCl} 2$, and $\mathrm{Ca}(\mathrm{OCl}) 2$. Different results were observed with the application of different sterilizing agents for different durations. Effect of different surface sterilization treatments on explants of $D$. hamiltonii depicted in table 1, no. of shoots/clumps and Shooting-length $(\mathrm{cm})$ in table 2 and average root number with rooting in table 3. According to the data record appropriate agent is $\mathrm{HgCl} 2$ for 20 minutes of treatment whereas the percentage of Aseptic buds and the percentage of bud break were $77.80 \%$ and $72 \%$ respectively. The application of $\mathrm{Ca}(\mathrm{OCl}) 2$ for 15 minutes gave $36.57 \%$ of Aseptic buds and $46 \%$ of Bud-break. Maximum multiplication was recorded at BA $(2.0 \mathrm{mg} / \mathrm{l})$ and maximum shoot length at $\mathrm{BA}(1.5 \mathrm{mg} / \mathrm{l})$ and rooting data record was predicted that the ideal condition for rooting is at concentration IAA+IBA+NAA $(1.00 \mathrm{mg} / \mathrm{l})$. The application of $2 \mathrm{mg} / \mathrm{l}$ concentration of Benzyl aminopurine; it results in $14.77 \pm 3.37$ and (no. of shoots/clumps) and 3.00 \pm 0.4 (length of shoots in c.m.). Similarly, the applications of growth regulators of IAA+IBA+NAA in the concentration of $1 \mathrm{mg} / \mathrm{l}$ results in $72.5 \pm 0.3$ (rooting) and $11.1 \pm 0.3$ (Av. No. of the root). A comparative study of kinetin and Benzyl aminopurine- effective use on shooting results that BA is most effective than $\mathrm{Kn}$. Adopting appropriate sterilization techniques gave good results.

Table 1. Effect of different surface sterilization treatments on Explants of D. hamiltonii collected from Pauhaddi Darbhanga

$\begin{array}{lll}\text { Treatments } & \text { Aseptic Buds }(\%) & \text { Bud break (\%) } \\ \mathrm{HgCl} 2 \text { (10minutes) } & 41.42 & 69.7 \\ \mathrm{HgCl} 2 \text { (15minutes) } & 67 & 54.3 \\ \mathrm{HgCl} 2 \text { (20minutes) } & 77.80 & 72 \\ \mathrm{Ca}(\mathrm{OCl}) 2 \text { (10minutes) } & 17.31 & 29.63 \\ \mathrm{Ca}(\mathrm{OCl}) 2 \text { (15minutes) } & 36.57 & 46 \\ \mathrm{Ca}(\mathrm{OCl}) 2 \text { (20minutes) } & 18.62 & 22\end{array}$


Micropropagation techniques produced the improved quality of clones with the treatment of different growth hormones in different concentrations like BA, IAA, IBA, NAA, and Kinetin. According to the data record BA $(2.0 \mathrm{mg} / \mathrm{l})$ gave maximum multiplication rate whereas maximum shoot length was observed at 1.5 $\mathrm{mg} / \mathrm{l}$. According to the data record, ideal results of rooting were observed at NAA $(5.0 \mathrm{mg} / \mathrm{l})$ and maximum rooting was observed at IAA+IBA+NAA $(1.0 \mathrm{mg} / \mathrm{l})$. In an earlier study, only $30 \%$ rooting was reported in 4weeks in D. hamiltonii shoots cultured on IBA or NAA supplemented media (Sood et al. 2002a and 2002b).

Table 2. Shooting data of D. hamiltonii collected from Pauhaddi Darbhanga

$\begin{array}{lll}\begin{array}{l}\text { Growth } \\ \text { regulators }(\mathrm{mg} / \mathrm{l})\end{array} & \begin{array}{l}\text { No. of } \\ \text { shoots/clumps }\end{array} & \begin{array}{l}\text { Shooting- } \\ \text { length }(\mathrm{cm})\end{array} \\ \text { Kn } 0.25 & 1.6 \pm 1.1 & 1.1 \pm 0.05 \\ \text { Kn } 0.50 & 1.3 \pm 0.47 & 1.1 \pm 0.32 \\ \text { Kn } 1.00 & 2.06 \pm 1.50 & 2.0 \pm 1.1 \\ \text { Kn } 1.50 & 2.25 \pm 1.3 & 3.02 \pm 1.21 \\ \text { Kn } 2.0 & 3.65 \pm 2.07 & 1.1 \pm 0.05 \\ \text { BA } 0.25 & 4.01 \pm 2.2 & 3.24 \pm 0.5 \\ \text { BA } 0.50 & 4.46 \pm 2.02 & 3.22 \pm 1.3 \\ \text { BA } 1.0 & 7.00 \pm 1.4 & 4.01 \pm 0.3 \\ \text { BA } 1.5 & 10.3 \pm 2.44 & 4.3 \pm 0.4 \\ \text { BA } 2.0 & 14.77 \pm 3.37 & 3.00 \pm 0.4\end{array}$

Table 3. Rooting data of D. hamiltonii collected from Pauhaddi Darbhanga Auxins concentrations (mg/l)

NAA 1.00

NAA2.00

NAA3.00

NAA5.00

IBA 1.00

IBA 2.00

IBA 3.00

IBA 5.00

IBA 7.00

$\mathrm{IAA}+\mathrm{IBA}+\mathrm{NAA}$

(S1.0)

\section{CONCLUSION}

With experimental study, we depicted that through micropropagation technique control over the traditional methods of propagation were done very easily and a comparative study of effects of growth regulators were summarized by collected data. High multiplication rate, better rooting proficiency and easy establishment in the soil were observed

\section{REFERENCES}

Adarsh kumar, Mohinder Pal and Shiv Kumar, 1992. Mass production of field planting stock of Dendrocalamus hamiltonii vegetatively through macroproliferation. Indian Forester, 118: 638646.
Alam, M.K. 1982. A guide to eighteen species of bamboos from Bangladesh, second bulletin. Plant taxonomy series, p 29. FRI, Chittagong.

Lund, B.O., Miller, D.M., and Woods, J.S. 1993. Studies on $\mathrm{Hg}$ (II) - induced $\mathrm{H}_{2} \mathrm{O}_{2}$ formation and oxidative stress in-vivo and in-vitro in rat kidney mitochondria. Biochem. Pharmacology, 45(10): 2017-2024.

Masatoshi 1994. WATANAB: Report of forest tending on after-care program for the trial plantation project in Benakat, South Sumatra. 43pp.

Nadgir, A.L., Phadke, C.H., Gupta P.K., Parasharmi, V.A., Nair S. and Mascarenhas, A.F. 1984. Rapid multiplication of Bamboo by Tissue Culture. Silvae Genetica, 6:219-33.

Nath, M., Phukan, U., Barua, G., Devi, M., Barua, B. and Deka, P. C. 1986. Propagation of certain bamboo species from chemically treated culm cutting. Indian J. Forestry, 9 (2): 151-156.

Oyebanji, O. B., Nweke, O., Odebunmi, O., Galadima, N. B., Idris, M. S., Nnodi, U. N., and Ogbadu, G. H. 2009. Simple, effective and economical explant-surface sterilization protocol for cowpea, rice and sorghum seeds. African Journal of Biotechnology, 8(20), 5395-5399.

Ramanuja Rao, I.V. 1994. Delivery systems for planting materials: requirements and approaches. In Constraints to production of bamboos and rattan. Report of a consultation held on 13 May 1994, Bangalore, India. Report of a consultation held in Bangalore, India, 9-13May 1994. INBAR Technical Report No. 5. International Network for Bamboo and Rattan, New Delhi, India. pp. 143-158.

Rao, I. U., Rao, I. V. R. and Narang, V. 1985. Somatic embryogenesis and regeneration of plants in the bamboo, Dendrocalamus strictus. Plant Cell Rep., 4: 191-194.

Saxena, S. and Bhojwani, S. S. 1993. In vitro clonal multiplication of 4-year-old plants of bamboo, Dendrocalamus longispathus Kurz. In Vitro Cell. Dev. Biol., 1993, 29, 135-142.

Sharma, O.P. and Kaushal, S. K. 1985. Exploratory propagation of Dendrocalamus hamiltonii Munro by one node cuttings. Indian Forester, 111(3):135-139.

Sood, A., Ahuja, P.S., Sharma, M., Sharma, O.P. and Godbole, S. 2002a. In vitro protocols and field performance of elites of an important bamboo Dendrocalamus hamiltonii Nees et Arn. Ex Munro. Plant Cell Tissue Organ Cult. 71: 55-63.

Sood, A., Palni, L.M.S., Sharma, M., Chand, G. and Sharma, O.P. 2002b. Micropropagation of Dendrocalamus hamiltonii Munro (Maggar Bamboo) using explants taken from seed raised and field-tested plus plants. J. Plant Biol. 29: $125-132$ 
Yeh, M. L. and Chang, W. C. 1986a. Plant regeneration through somatic embryogenesis in callus culture of green bamboo (Bambusa oldhamii). Theor Appl Genet., 73: 161-163.
Yeh, M. L. and Chang, W. C. 1986b. Somatic embryogenesis and subsequent plant regeneration from inflorescence callus of Bambusa beecheyana Munro var. beecheyana. Plant Cell Rep., 5: 409-411.

Citation: Jha, A. and Das, S. 2021. Assessment of In-vitro culture through Nodal explants of Dendrocalamus hamiltonii. International Journal of Agricultural and Applied Sciences, 2(1):130-133. https://doi.org/10.52804/ijaas2021.2115

Copyright: (C) Jha and Das 2021. Creative Commons Attribution 4.0 International License. IJAAS allows unrestricted use, reproduction, and distribution of this article in any medium by providing adequate credit to the author(s) and the source of publication. 